\title{
Simulation of Bottom Phytocenosis in the Crimean Coastal Zone
}

\author{
E. F. Vasechkina*, T. A. Filippova \\ Marine Hydrophysical Institute of RAS, Sevastopol, Russian Federation \\ *e-mail: vasechkina.elena@gmail.com
}

Purpose. The work is aimed at simulating production processes in the bottom phytocenosis typical of the rocky soils in the Crimean coastal zone. The macroalgae uptake of the main nutrients (phosphates, ammonium and nitrates) and release of oxygen and dissolved compounds are planned to be estimated. Methods and Results. The study was based on the balance model of the macroalgae growth and interaction with the environment. The model empirical parameters were determined from the published data of the laboratory experiments. The bottom phytocenosis in the model was represented by seven algae species: Cystoseira barbata, Ulva lactuca, Ceramium tenuicorne, Cladophora glomerata, Polysiphonia nigrescens, Phyllophora truncata, Enteromorpha prolifera. The main simulation results were: annual estimates of the released and absorbed substances, seasonal dynamics of the macroalgae biomass and evaluation of the bottom phytocenosis response to the changing environmental conditions. The rate of the production processes in the model was influenced both by the external (water temperature, insolation and concentration of nutrients in water) and internal (intracellular quotas of nitrogen and phosphorus, and species-specific parameters determining efficiency of nutrient assimilation by the algae tissues) factors. According to the simulation results, the ratio of nitrogen to phosphorus in the algae tissues was significantly higher than that in the seawater and varied from 30 to 60 for different species depending on water temperature, light exposure and concentration of nutrients.

Conclusions. During the periods of intensive macroalgae growth (from April to September), the rate of nitrogen and phosphorus uptake can increase by a factor of 1.5 in comparison with the winter period. Maximum contribution to water purification from the surplus nutrients was made by the green algae: Ulva lactuca, Cladophora glomerata and Enteromorpha prolifera. At that Cladophora glomerata has shown the best adaptive abilities (minimal decrease in the growth rate) under a sharp drop of nutrients concentration in water.

Keywords: marine ecosystem, macroalgae, phytobenthos, photosynthesis, metabolic processes.

Acknowledgements: the investigation was carried out within the framework of state task No. 0827-2018-0004 ("Complex interdisciplinary investigations of the oceanologic processes conditioning functioning and evolution of the Black and Azov seas' coastal zones”) and at partial financial support of the RFBR grant No. 18-05-80028.

For citation: Vasechkina, E.F. and Filippova, T.A., 2020. Simulation of Bottom Phytocenosis in the Crimean Coastal Zone. Physical Oceanography, [e-journal] 27(3), pp. 317-334. doi:10.22449/1573-160X-2020-3-317-334

DOI: 10.22449/1573-160X-2020-3-317-334

(C) E. F. Vasechkina, T. A. Filippova, 2020

(C) Physical Oceanography, 2020

\section{Introduction}

Marine macroalgae are of great interest for research for several reasons. In the shallow coastal zone, phytobenthos is the main source of oxygen and a consumer of nutrients, the main of which are nitrogen and phosphorus. Macroalgae thickets partially offset the excess supply of nutrients to coastal waters as a result of economic activity. In [1], the role of bottom phytocenoses in the processes of self-purification of the Balaklava region coastal zone, polluted by domestic sewage and industrial slag waters from a sand pit, is studied. Positive macroalgae effect is observed in two directions - providing the aeration of ISSN 1573-160X PHYSICAL OCEANOGRAPHY VOL. 27 ISS. 3 (2020) 
the coastal zone and the reduction of nutrients in water. Of course, when cultivating algae in rather large areas, it is possible to achieve deep purification of the water area, which will exclude eutrophication of the coastal zone, and the aeration accompanying these processes will significantly improve water quality.

In recent years the mariculture activity, associated with the cultivation of macroalgae for the biological treatment of water, and as a component of integrated multitrophic aquaculture [2-4] has been actively developing. The issues related to the organization of mariculture farms for planting macroalgae are becoming relevant. For proper planning of a seaweed farm, many factors must be taken into account: chemical indicators of the environment, hydrological regime and economic characteristics of future production. Simulation of the macroalgae (which are planned to be planted) functioning helps to facilitate the selection of the optimal species for the region of interest.

To date, many works containing an analysis of laboratory research data on determining certain characteristics of metabolic processes in macroalgae, which are necessary for constructing a model, were published. In [5], the phytocenosis of Hornsund fiord was studied. The authors modeled the processes of photosynthesis and dark respiration. Photosynthesis curves were obtained for the selected algae, and environmental characteristics, mainly determining the vital processes of macroalgae in this region, were found. However, the kinetics of nutrient uptake and the release of organic compounds were not described. The study [6] was devoted to the modeling of phytocenosis characteristic of various regions of the World Ocean (for example, the North America coast, the Baltic Sea, the New Zealand coast). The link between the plant morphology and the processes of nutrient absorption were established. The simulation results are quantitative characteristics of the kinetics of nitrogen compounds uptake. In [7], the results of a study of the nutrient uptake kinetics by some species of macroalgae of the Baltic Sea and the Skagerrak Strait are presented. The processes of ammonium, nitrates and phosphorus uptake are considered, and the kinetics of algae in the tidal zone is also described at a qualitative level.

In [8], photosynthesis curves were obtained empirically for 27 species of macroalgae in the western Baltic Sea. It was shown that the photosynthesis intensity is seasonal and annual plants with a large surface area have the highest biomass productivity. In the study [9], a functional relationship between the specific surface area and the growth rate of micro- and macroalgae are revealed. The work is of interest due to the fact that both field data and simulation results are considered, however, the temperature effect on the algae growth rate is not taken into account. All the results are obtained for $15-20{ }^{\circ} \mathrm{C}$ temperature range.

The work [10] is devoted to the study of the processes of algae growth and nutrients uptake under conditions of varying salinity. Despite the fact that only three types of brown algae were considered, the authors presented a detailed analysis of the most important processes that determine the growth rate of plants. The studies have shown that a variation in the growth rate is observed only when the salinity is halved compared to the optimal one for this species. It has been shown that macroalgae have great plasticity with respect to the changing external concentration of nutrients, which is ensured by a wide range of their content in 
tissues. In [11], the salinity effect on the intensity of metabolic processes for two types of macroalgae - Gracilaria and Ulva - was studied. The experiments demonstrated that salinity does not significantly affect the growth of plants.

The objective of [12] was also to study the relationship between the kinetics of nitrogen uptake and the specific surface of thalli. The authors give a comparative description of nitrogen uptake kinetics by micro- and macroalgae, demonstrating the correlation between the specific surface area and the rate of nitrates and ammonium removal. The work emphasizes that the larger the surface area of the plant, the more intensive the removal of nutrients from the environment. It is proposed to combine algae similar in morphology into groups and to determine the average surface area of plants within the group, since single definitions of area are not reliable enough. This approach was developed in [13], where it was proposed to apply the assessment method, based on the power-law dependences of physiological process characteristics on the specific surface of the algae, to the average groups of algae. 44 species of macroalgae, which are divided into 6 morpho-functional groups in accordance with the structural features of the thalli, are considered. For group averages, power-law dependencies on the specific surface were constructed to determine the rate of photosynthesis, respiration costs, and nitrogen content in tissues.

Ecological models often use the Redfield ratio, which reflects a fixed ratio between nitrogen, phosphorus and carbon in macroalgae tissues. However, in [14] it was revealed that this ratio for macrophytes is substantially violated. The internal content of nutrients in tissues is determined by the element concentration in the external environment and the needs of the plant during the growth of its tissues and can vary significantly over time.

The listed works contain various aspects of marine phytocenosis modeling, however, a more comprehensive approach was considered in [15]. The proposed model formalized the processes of photosynthesis, uptake of nitrogen and phosphorus from sea water, as well as the release of dissolved organic compounds into the environment. The control variables of the model are the concentration of nitrogen and phosphorus in water, water temperature and insolation. The salinity is not considered in the model since for the area under study its significant fluctuations, which could affect the macroalgae physiology, were not observed.

The purpose of this work is to expand the results obtained in [15] for one macroalgae species to a bottom phytocenosis typical for the Crimean coastal zone.

\section{Materials and methods}

In the Black Sea Crimean coastal region, three types of bottom phytocenosis can be distinguished: Zostera phytocenosis typical for a sandy bottom, Cystoseira phytocenosis - growing on rocky soil and Phyllophora phytocenosis. The Cystoseira complex transforms into a Cystoseira - Phyllophora community with depth. Earlier, the lower boundary of the Cystoseira thickets was indicated at 15-20 m depth, now it is usually determined at $10 \mathrm{~m}$ depth and already at 6-9 m depth in the phytocenosis two species of Cystoseira and Phyllophora prevail [16]. 
The concomitant algae and epiphytes are a part of Cystoseira phytocenosis; their percentage ratio in biomass can vary significantly. According to numerous literature data, the accompanying algae species (both macro- and microalgae) are the main consumers of nutrients. They are also the main source of oxygen, unlike basiphyte, which, as a rule, is the least active participant in these processes. However, the biomass of basiphyte prevails over the biomass of related species, which allows it to make a significant contribution to the fluxes of oxygen and nutrients despite the lower metabolic rate.

In order to assess the fluxes of consumed and excreted substances, a phytocenosis of Cystoseira, typical for the Crimean coastal zone, was chosen. Two types of plants are a basiphyte for this complex: Cystoseira crinita and Cystoseira barbata - representatives of the brown algae class. Both plants are perennial and are characterized by a high content of alginic acid. An adult plant is a massive branched bush of $0.5-1 \mathrm{~m}$ height attached to a rocky soil. An unattached Cystoseira form is also present in the Black Sea but its share is much lower compared to the attached form and it does not form a phytocenosis. A tall bush with a well-branched thallus, firmly attached to the soil, acts as a good basiphyte: it is convenient for concomitant plant species to settle near the Cystoseira thallus, as well as directly on it [17]. Macroalgae can grow near the basiphyte, and microalgae can grow directly on its thallus.

For simulatig the dynamics of phytocenosis, we selected 7 macroalgae species typical for the Crimean coast: Cystoseira barbata, Ulva lactuca, Ceramium tenuicorne, Cladophora glomerata, Polysiphonia nigrescens, Phyllophora truncata, Enteromorpha prolifera [16]. Phyllophora is a representative of the red algae phyllum, grows mainly on a rocky bottom at 0-60 m depths; the plant is a bush up to $50 \mathrm{~cm}$ high, the thallus has the appearance of branched ribbons; in $10-25 \mathrm{~m}$ depth range it is often a basiphyte, however, in our case, the model phytocenosis was located at $5 \mathrm{~m}$ depth, and under these conditions the phyllophore does not prevail over the rest of the plants and acts as a concomitant species [18]. Ceramium is also a representative of red algae, the thallus is a well-branched bush with thin branches, the height of the plant is up to $15 \mathrm{~cm}$; this species is found in almost all the seas [19]. Ulva is a representative of green algae, thallus is a thin leaf, the height of the plant is within the range from a few centimeters to $1 \mathrm{~m}$. The distribution is quite extensive, small-sized plants are often found in the coastal waters of the Black Sea [20]. Cladophora also belongs to the group of green algae, the plant has the appearance of a well-branched bush, thalli are long strings, consisting of one row of consecutive cells; widespread in the coastal waters of Crimea [19]. Polysiphonia is red algae, the plant looks like a highly branched bush reaching a height of $30 \mathrm{~cm}$, thalli are long thin filaments. The geography of its distribution is quite extensive. It also occurs in the Black Sea, the depth of growth reaches $20 \mathrm{~m}$ [19]. Enteromorpha is a representative of green algae, a family of Ulva. The plant bush has a look similar to Ulva, however, Enteromorpha is smaller (up to $20 \mathrm{~cm}$ in height) and thallus in the form of thin filaments; widespread in the Black and Azov Seas [19]. 


\section{Mathematical model}

The mathematical model of phytocenosis functioning was based on the macroalgae growth model described in detail in [15]. For each alga included in the phytocenosis, the following equation was solved

$$
\frac{d B}{d t}=\left(P_{r}-E-m\right) B,
$$

where $B\left(\mathrm{~g} / \mathrm{m}^{2}\right.$ or $\left.\mathrm{g} / \mathrm{m}^{3}\right)$ is a macroalgae biomass, in units of dry weight; $P_{r}(1 / \mathrm{h})$ is a specific growth rate; $E(1 / \mathrm{h})$ is a specific rate of release of dissolved organic matter (DOM) during the algae life [17]; $m(1 / \mathrm{h})$ is a mortality coefficient that takes into account the processes of destruction and decay of plant branches, biomass loss due to grazing by marine organisms.

The specific growth rate $P_{r}$ is determined by the rate of photosynthesis, depending on the species specific characteristics of the algae and external conditions (insolation, water temperature), as well as the reserves of necessary nutrients in the plant tissues:

$$
\begin{gathered}
P_{r}=P_{p} \min \left(f\left(Q_{\mathrm{N}}\right), f\left(Q_{\mathrm{P}}\right)\right), \\
P_{p}=\left\{P_{\max } \tanh \left(\alpha \frac{I}{p_{\max }}\right)+R_{d}\right\} f(T), \\
f\left(Q_{\mathrm{N}}\right)=\frac{Q_{\mathrm{N}}-Q_{\mathrm{N}}^{\min }}{Q_{\mathrm{N}}^{\max }-Q_{\mathrm{N}}^{\min }}, \\
f\left(Q_{\mathrm{P}}\right)=\frac{Q_{\mathrm{P}}-Q_{\mathrm{P}}^{\min }}{Q_{\mathrm{P}}^{\max }-Q_{\mathrm{P}}^{\min }}, \\
I=I_{0} \mathrm{e}^{-0,01 h}, \\
f(T)=\sin \left(\frac{2 \pi T}{100}+0,2\right),
\end{gathered}
$$

where $I_{0}(\mu \mathrm{mol}$ photons $/ \mathrm{m} 2 / \mathrm{s})$ is a photosynthetically active radiation (PAR) on the water surface, $I-$ at $h(\mathrm{~m})$ depth; $P_{p}\left(\mathrm{mg} \mathrm{O}_{2} / \mathrm{g} / \mathrm{h}\right)$ is a photosynthesis rate; $P_{\max }\left(\mathrm{mg} \mathrm{O}_{2} / \mathrm{g} / \mathrm{h}\right)$ is a maximum photosynthesis rate; $\alpha$ is the slope of $P I$-curve for small values of the light flux; $R_{d}$ (mg $\mathrm{O}_{2} / \mathrm{g} / \mathrm{h}$ ) is a dark respiration (characterizes the amount of oxygen expended in respiration in the dark); $Q_{\mathrm{P}}$ and $Q_{\mathrm{N}}(\mu \mathrm{mol} / \mathrm{g})$ is the concentration of phosphorus and nitrogen in the algae tissues; $Q_{\mathrm{P}}^{\min }, Q_{\mathrm{P}}^{\max }, Q_{\mathrm{N}}^{\min }, Q_{\mathrm{N}}^{\max }$ ( $\mu \mathrm{mol} / \mathrm{g}$ ) is the minimum and maximum concentrations of phosphorus and nitrogen in the algae tissues; $T\left({ }^{\circ} \mathrm{C}\right)$ is the water temperature.

The photosynthetic parameters (maximum photosynthesis rate, PI-curve slope, respiration costs and $E_{c}-$ PAR value at which respiration oxygen costs are balanced by photosynthesis) are species-specific and also depend on a number of 
conditions, the main of which is water temperature. For all 7 macroalgae species included in the phytocenosis model, a search for laboratory experiments to determine the parameters of the photosynthesis curve (Table 1) was carried out. The extreme values of nitrogen and phosphorus content in the tissues were assumed to be the same for all algae due to the lack of more detailed information. In accordance with the data of [21], where the taxons of green, red and brown algae were analyzed, the variability ranges of nitrogen content 850-2571 $\mu \mathrm{mol} \mathrm{N/g}$ and phosphorus 27.64-80.06 $\mu \mathrm{mol} \mathrm{P} / \mathrm{g}$ were taken.

Table 1

Photosynthetic parameters of macroalgae in the model phytocenosis

\begin{tabular}{|c|c|c|c|c|c|}
\hline Species & $P_{\max }\left(\mathrm{mg} \mathrm{O}_{2} / \mathrm{g} / \mathrm{h}\right)$ & $R_{d}\left(\mathrm{mg} \mathrm{O}_{2} / \mathrm{g} / \mathrm{h}\right)$ & $\alpha(\Delta P / \Delta I)$ & $E_{c}\left(\mu \mathrm{mol}\right.$ photon $\left./ \mathrm{m}^{2} / \mathrm{s}\right)$ & Source \\
\hline $\begin{array}{l}\text { Cystoseira } \\
\text { barbata }\end{array}$ & 3.58 & 0.80 & 0.12 & 18 & [22] \\
\hline Ulva lactuca & 28.00 & 2.97 & 0.45 & 7 & [23] \\
\hline $\begin{array}{l}\text { Ceramium } \\
\text { tenuicorne }\end{array}$ & 12.31 & 2.88 & 0.13 & 22 & [7] \\
\hline $\begin{array}{l}\text { Cladophora } \\
\text { glomerata }\end{array}$ & 27.50 & 2.00 & 0.13 & 10 & [8] \\
\hline $\begin{array}{l}\text { Polysiphonia } \\
\text { nigrescens }\end{array}$ & 11.12 & 2.59 & 0.11 & 23 & [8] \\
\hline $\begin{array}{l}\text { Phyllophora } \\
\text { truncata }\end{array}$ & 2.45 & 0.74 & 0.04 & 21 & [7] \\
\hline $\begin{array}{l}\text { Enteromorpha } \\
\text { prolifera }\end{array}$ & 41.00 & 1.80 & 0.15 & 17 & [8] \\
\hline
\end{tabular}

The rate of dissolved mineral forms of nitrogen and phosphorus uptake depends on their concentration in the sea water and the stored reserves of this element in alga tissues. The nitrogen and phosphorus content in the tissues is regulated by the balance between the consumption of these elements during the alga growth and the supply as a result of uptake from the sea water:

$$
\begin{gathered}
\frac{d Q_{\mathrm{N}}}{d t}=V_{\mathrm{NO}_{3}} \frac{\left[\mathrm{NO}_{3}\right]}{K_{\mathrm{NO}_{3}}+\left[\mathrm{NO}_{3}\right]}+V_{\mathrm{NH}_{4}} \frac{\left[\mathrm{NH}_{4}\right]}{K_{\mathrm{NH}_{4}}+\left[\mathrm{NH}_{4}\right]}-P_{r} Q_{\mathrm{N}}, \\
\frac{d Q_{\mathrm{P}}}{d t}=V_{\mathrm{P}} \frac{[\mathrm{P}]}{K_{\mathrm{P}}+[\mathrm{P}]}-P_{r} Q_{\mathrm{P}}, \\
V_{\mathrm{NO}_{3}}=V_{\mathrm{NO}_{3}}^{\max }\left(1-f\left(Q_{\mathrm{N}}\right)\right), \\
V_{\mathrm{NH}_{4}}=V_{\mathrm{NH}_{4}}^{\max }\left(1-f\left(Q_{\mathrm{N}}\right)\right), \\
V_{\mathrm{P}}=V_{\mathrm{P}}^{\max }\left(1-f\left(Q_{\mathrm{P}}\right)\right),
\end{gathered}
$$

where $V_{\mathrm{NO}_{3}}^{\max }, V_{\mathrm{NH}_{4}}^{\max }, V_{\mathrm{P}}^{\max }(\mu \mathrm{mol} / \mathrm{g} / \mathrm{h})$ are the maximum possible uptake rates at a sufficiently high concentration of nutrient in the water; $K_{\mathrm{NO}_{3}}, K_{\mathrm{NH}_{4}}, V_{\mathrm{P}}(\mu \mathrm{M})$ are 
the concentrations of inorganic compounds of phosphorus and nitrogen at which the removal rates reach half of their maximum value.

The specific rate of DOM release during the alga life ( $E$ value in the equation (1)), in turn, depends on the temperature and intensity of PAR flux. In the daytime $E$ is directly proportional to the growth rate $P_{r}$, in the dark - to the rate of dark respiration of the algae. In the model, the rate of metabolite excretion was set by the formulas for daylight and dark time, respectively:

$$
\begin{aligned}
& E \sim k_{1} P_{r}, \\
& E \sim k_{2} R_{d},
\end{aligned}
$$

where $k_{1}$ and $k_{2}$ are the proportionality factors.

The mortality coefficient $m$ in (1) takes into account all the processes associated with weight loss, which can be caused both by internal processes (the natural death of alga tissues during the life cycle) and by external ones: thalli grazing by marine organisms, separation of plant branches under mechanical action. In each case, the mortality rate for the same species will vary, and taking into account the wide variety of factors causing the loss of mass by the plant, this value cannot be determined quite accurately. Therefore, in our model the mortality rate is the only adjustable parameter. Its value was selected in such a way as to limit the range of biomass variability within the observed one for a sufficiently long time for a given seasonal dynamics of nutrients concentrations in water. In the practical application of the model, this coefficient should be selected in such a way as to reconstruct the actual biomass distribution of the phytocenosis various components in the computational domain for a given range of the control variables variability . Further in the text, the analysis of the results of performed numerical experiments concerns only specific growth and metabolism rates, which are independent of the absolute biomass values.

Table 2

\begin{tabular}{|c|c|c|c|c|c|c|c|}
\hline Species & $K_{\mathrm{NH}_{4}}$ & $V_{\mathrm{NH}_{4}}^{\max }$ & $K_{\mathrm{NO}_{3}}$ & $V_{\mathrm{NO}_{3}}^{\max }$ & $K_{\mathrm{P}}$ & $V_{\mathrm{P}}^{\max }$ & Source \\
\hline Cystoseira barbata & 16.09 & 37.15 & 9.08 & 8.65 & 0.29 & 0.06 & {$[15,26]$} \\
\hline Ulva lactuca & 20.00 & 211.00 & 34.00 & 116.00 & 4.41 & 9.31 & [27] \\
\hline Ceramium tenuicorne & 16.93 & 143.43 & 3.91 & 18.67 & 1.00 & 0.78 & [25] \\
\hline Cladophora glomerata & 32.68 & 327.83 & 5.27 & 115.72 & 0.33 & 3.06 & [25] \\
\hline $\begin{array}{l}\text { Polysiphonia } \\
\text { nigrescens }\end{array}$ & 23.90 & 138.18 & 14.01 & 49.89 & 4.47 & 7.39 & [15] \\
\hline Phyllophora truncata & 7.93 & 9.71 & 9.21 & 1.69 & 0.37 & 0.12 & [24] \\
\hline $\begin{array}{l}\text { Enteromorpha } \\
\text { prolifera }\end{array}$ & 13.40 & 188.00 & 13.30 & 169.00 & 1.51 & 4.59 & [25] \\
\hline
\end{tabular}

Kinetic parameters of macroalgae in the model phytocenosis 
An important stage in the phytocenosis modeling is to obtain kinetic relationships describing the processes of nutrients uptake from the sea water. The empirical coefficients in these dependences were obtained from [24-27] (Table 2). For two types of phytocenosis algae - Cystoseira (only for nitrogen compounds) and Polysiphonia - it was impossible to determine reliably the kinetic parameters from the published data. For setting them, the approach proposed in [15], which allows one to obtain the assessments of required kinetic parameters as functions of the average specific surface of thalli within the morpho-functional group, was applied:

$$
\begin{aligned}
K_{\mathrm{NO}_{3}} & =\frac{V_{\mathrm{NO}_{3}}^{\max }}{0,1255 \cdot S V^{0,5848}}, \\
K_{\mathrm{NH}_{4}} & =\frac{V_{\mathrm{NH}_{4}}^{\max }}{0,5635 \cdot S V^{0,407}}, \\
K_{\mathrm{P}} & =\frac{V_{\mathrm{P}}^{\max }}{0,0093 \cdot S V^{0,9056}}, \\
V_{\mathrm{NO}_{3}}^{\max } & =0,5857 \cdot S V^{0,777}, \\
V_{\mathrm{NH}}^{\max } & =4,9328 \cdot S V^{0,5826}, \\
V_{\mathrm{P}}^{\max } & =0,0564 \cdot S V^{0,8523},
\end{aligned}
$$

where $S V(1 / \mathrm{m})$ is a specific alga surface, i.e. a ratio of surface area to the thallus volume. For Cystoseira we took $S V=32$, for Polysiphonia $S V=305$ [9].

\section{Discussion of the results}

For verifying the model, the numerical experiments on simulating the seasonal dynamics of processes in the bottom phytocenosis were carried out. The control variables of the model are given in Fig. 1. The diurnal variation was included into the data on insolation; negative values were replaced by zero. For simulating the variable cloud cover, white noise was added to the obtained series.
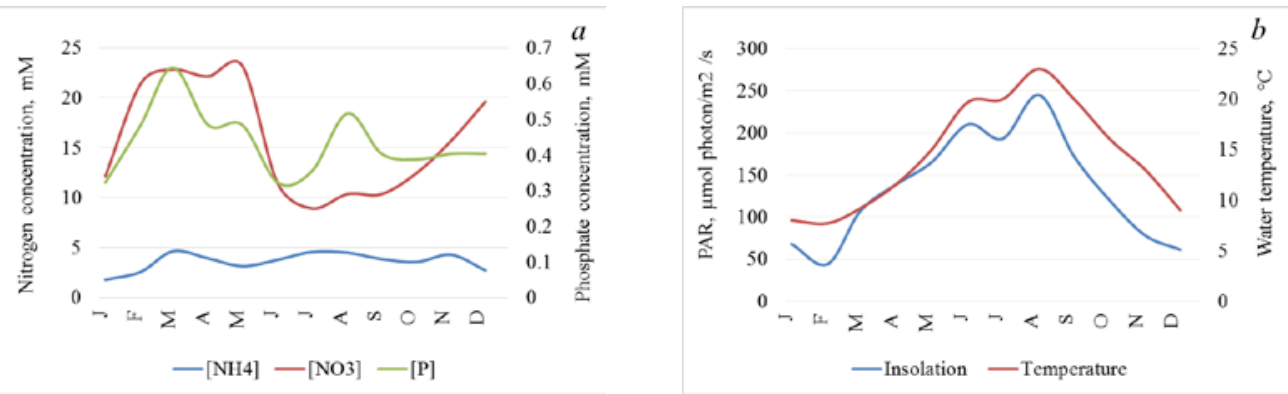

F i g. 1. Control variables in the experiment on simulating seasonal dynamics: average concentrations of nitrates, ammonium and phosphates in the Yalta port region (2005-2010) [28] (a); seasonal variation of water temperature and PAR over the Black Sea [29] (b) 

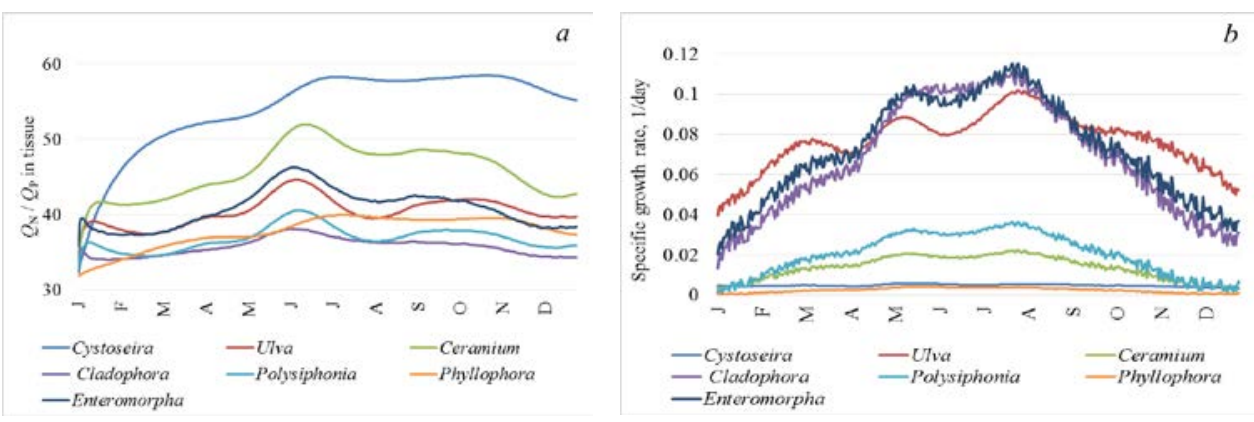

F i g. 2. N/P ratio in the macroalgae tissues (a) and specific growth rate $(b)$

Rather wide range of ratios of biomass of various macroalgae species constituting phytocenosis is known from the observations. At the initial moment, the following ratio was set in the model: $64 \%$ - Cystoseira, $6 \%$ - for each of associated species. The nitrogen and phosphorus content in the algae tissues was set to be equal to half of the saturation level. Fig. 2, $a$ illustrates the setting of a quasi-stationary $\mathrm{N} / \mathrm{P}$ ratio in tissues, determined by the nitrogen and phosphorus concentration in the environment and the growth rate of algae (Fig. 2, $b$ ).

The quasi-stationary N/P ratios in algae tissues obtained in the model are consistent with the experimental data published in [14, 21,30]. The ratio of nitrogen to phosphorus in algae tissues varies within the range of 30-60 for different species and depends on water temperature and light. A significant increase in the demand for nutrients due to an increase in the growth rate at the peak of the vegetation period does not lead to noticeable changes in the ratio of nitrogen and phosphorus in the tissues. Apparently, the cause for this is a flexible mechanism of algae adaptation to varying conditions, manifested in an increase in the uptake rate of necessary elements from the environment when they are insufficiently contained in the tissues. This increase can reach $150 \%$ compared to the winter level of uptake. The specific growth rates of algae obtained in the model do not contradict the assessments known from observational data [13]. In Fig. 3 the seasonal biomass dynamics of all components of the model phytocenosis and its structure is represented.
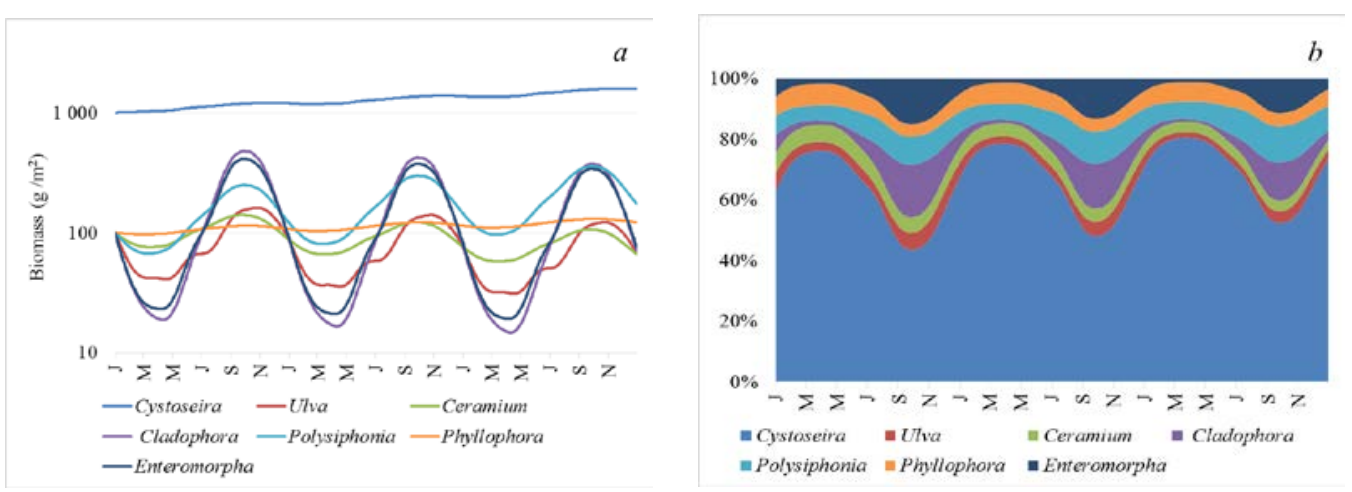

F i g. 3. Modeling of seasonal biomass dynamics of the algae constituting bottom phytocenosis (a) and the phytocenosis structure (b) 
During the period from May to November the phytocenosis structure significantly changes, the biomass of annual species increases, as a result of which the proportion of Cystoseira decreases to $40 \%$. The rate of metabolic processes in annual algae is higher than that of basiphyte (Cystoseira), which is due to a larger specific surface area of thalli $[8,12,13,31]$. Accordingly, the amount of uptaken nutrients and oxygen released by these species per kilogram of dry weight is higher. According to the simulation results, the volumes of released and uptaken substances by the tissues of all macroalgae that make up the phytocenosis were evaluated.
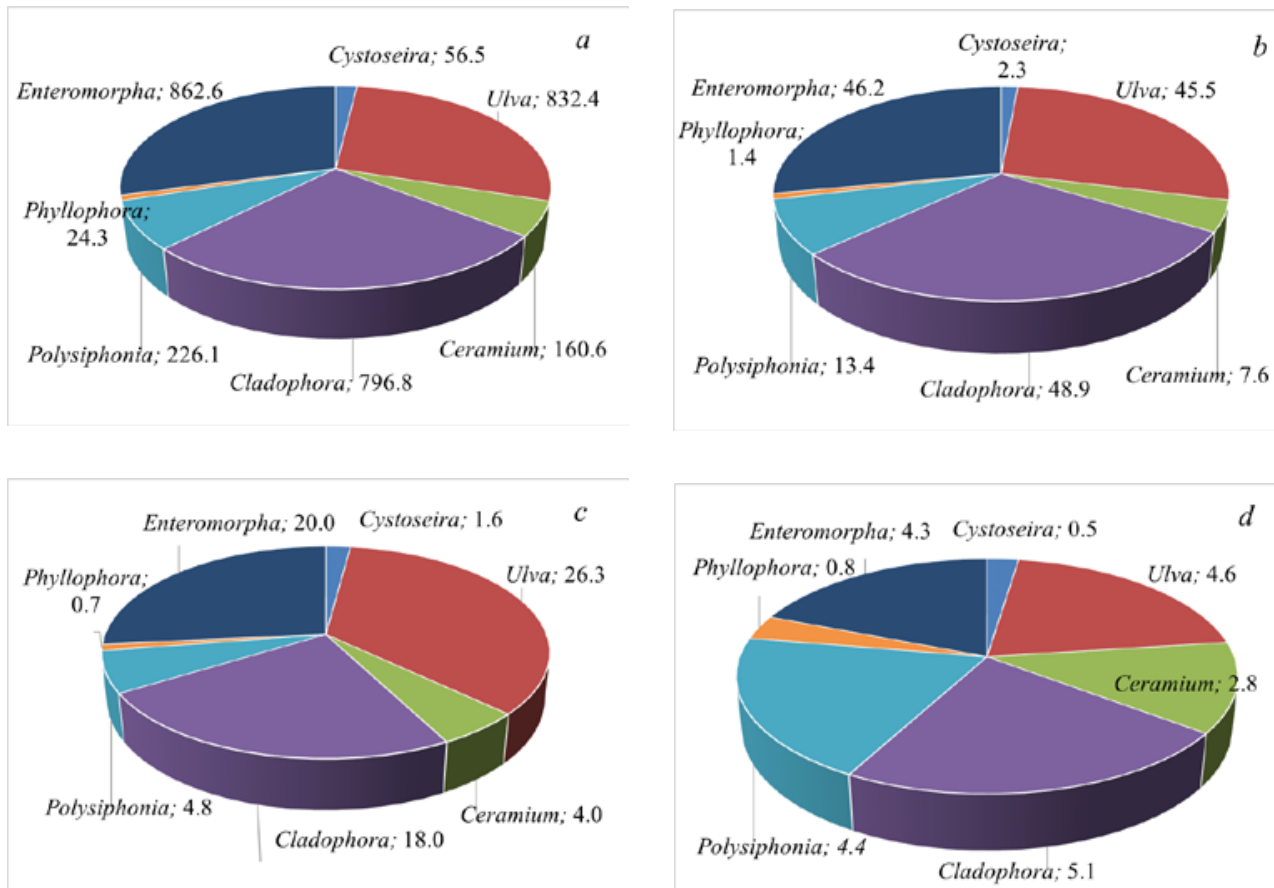

Fig. 4. Annual specific uptake and release of matter by macroalgae: $a$ - uptake of nitrates and ammonium (g N/kg/year); $b$ - phosphate uptake (g P/kg/year); $c$ - released oxygen ( $\mathrm{kg} \mathrm{O}_{2} / \mathrm{kg} /$ year); $d$ released dissolved organic matter $(\mathrm{kg} \mathrm{C} / \mathrm{kg} /$ year)

The mass of nitrogen and phosphorus uptake calculated by the algae growth rate and the content of these elements in the tissues is given in Fig. 4. Total uptake can also be calculated from uptake rates $V_{\mathrm{NO}_{3}}, V_{\mathrm{NH}_{4}}, V_{\mathrm{p}}$, however, these assessments will be overestimated since algae during life activity release dissolved organic matter, which also contains organic compounds of nitrogen and phosphorus in addition to carbon.

In the diagrams of Fig. 4 the masses of uptaken and released substances are given in grams of the corresponding element per kilogram of dry weight of algae tissue. It is also of interest to consider the same distribution in proportions, i.e. 
the relative contribution of each component of phytocenosis to the overall process of uptake of inorganic compounds and the release of organic matter and oxygen (here it is assumed that the biomass of all components of phytocenosis per $1 \mathrm{~m}^{2}$ of area are equal to each other). The contribution of each component of the bottom phytocenosis to metabolic processes in percent is presented in Table. 3.

Table 3

Annual specific uptake and release of matter (\%) by macroalgae (provided the biomasses of all the components are equal)

\begin{tabular}{l|rr|c|c}
\hline \multirow{2}{*}{ Species } & \multicolumn{2}{|c|}{ Uptake } & \multicolumn{2}{c}{ Release } \\
\cline { 2 - 4 } & nitrogen & phosphorus & oxygen & organic substance \\
\cline { 1 - 1 } Cystoseira barbata & 1.9 & 1.4 & 2.1 & 2.4 \\
\cline { 1 - 1 } Ulva lactuca & 28.1 & 27.5 & 34.9 & 20.6 \\
\cline { 1 - 1 } Ceramium tenuicorne & 5.4 & 4.6 & 5.3 & 12.4 \\
\cline { 1 - 1 } Cladophora glomerata & 26.9 & 29.5 & 24.0 & 22.5 \\
\cline { 1 - 1 } Polysiphonia nigrescens & 7.6 & 8.1 & 6.3 & 19.8 \\
\cline { 1 - 1 } Phyllophora truncata & 0.8 & 0.9 & 0.9 & 3.3 \\
\cline { 1 - 1 } Enteromorpha prolifera & 29.1 & 27.9 & 26.5 & 19.0 \\
\hline
\end{tabular}

As we see, the effect of various components on the processes of the phytocenosis interaction with the environment is very different. The greatest contribution to the water purification from nutrients is made by green algae - Ulva, Cladophora and Enteromorpha. The same algae release oxygen most intensively, contributing to the bottom layer aeration. . Red algae contribution to the processes of nutrients uptake is not so great, while they release DOM more actively than green algae (Fig. 4, d). As for the Cystoseira, its contribution (in specific terms) to the processes of nutrients uptake and oxygen evolution is small compared to other algae. However, taking into account the fact that in the phytocenosis its biomass significantly exceeds the one of related species and epiphytes, Cystoseira contribution to water purification and aeration is quite significant. The assessments of absorbed and released substances per $1 \mathrm{~m}^{2}$ of the bottom phytocenosis area, taking into account the ratios of its components in terms of biomass obtained in the model during the year, are given in the Table 4 .

Unfortunately, the information for verifying the model from observational data in the Crimean Peninsula coastal zone is currently insufficient. The calculated volumes of oxygen release, uptake of nitrates and phosphates, which are based on rough assessments of the total phytobenthos biomass in semi-enclosed waters, are published in literary sources [2,32]. Information on the intensity of metabolic PHYSICAL OCEANOGRAPHY VOL. 27 ISS. 3 (2020) 
processes of macrophytes per unit mass is not available. In addition, our simulation experiments used long-term average data on the temperature and solar radiation on the sea surface, which are the control variables for the model calculations. Thus, the obtained model assessments can be compared with field data only in order of magnitude. Such a comparison gives a satisfactory result. More accurate studies require more research.

Table 4

Annual average biomass and total indicators of intensity of the phytocenosis metabolic processes based on the results of the simulation experiments

\begin{tabular}{|c|c|c|c|c|c|}
\hline \multirow{2}{*}{ Macroalgae species } & \multirow{2}{*}{$\begin{array}{c}\text { Average } \\
\text { biomass } \\
\left(\mathrm{g} / \mathrm{m}^{2}\right)\end{array}$} & \multicolumn{2}{|c|}{ Uptake during a year } & \multicolumn{2}{|c|}{ Release during a year } \\
\hline & & $\begin{array}{c}\text { nitrogen } \\
\text { (g N/m² /year) }\end{array}$ & \begin{tabular}{|c|} 
phosphorus \\
(g $\mathrm{P} / \mathrm{m}^{2} /$ year)
\end{tabular} & $\begin{array}{c}\text { oxygen } \\
\mathrm{kg} \mathrm{O}_{2} / \mathrm{m}^{2} / \text { year) }\end{array}$ & $\begin{array}{c}\mathrm{DOM} \\
\left(\mathrm{kg} \mathrm{C} / \mathrm{m}^{2} / \text { year }\right)\end{array}$ \\
\hline Cystoseira barbata & 1119.65 & 63.22 & 2.59 & 1.76 & 0.60 \\
\hline Ulva lactuca & 232.50 & 192.46 & 10.43 & 6.10 & 1.10 \\
\hline $\begin{array}{l}\text { Ceramium } \\
\text { tenuicorne }\end{array}$ & 271.57 & 41.56 & 1.95 & 1.04 & 0.78 \\
\hline $\begin{array}{l}\text { Cladophora } \\
\text { glomerata }\end{array}$ & 129.08 & 104.87 & 6.43 & 2.38 & 0.70 \\
\hline $\begin{array}{l}\text { Polysiphonia } \\
\text { nigrescens }\end{array}$ & 334.02 & 71.40 & 4.22 & 1.51 & 1.57 \\
\hline $\begin{array}{l}\text { Phyllophora } \\
\text { truncata }\end{array}$ & 92.60 & 2.26 & 0.13 & 0.06 & 0.07 \\
\hline $\begin{array}{l}\text { Enteromorpha } \\
\text { prolifera }\end{array}$ & 222.69 & 191.27 & 10.20 & 4.44 & 1.00 \\
\hline
\end{tabular}

Simulation allows one to study the system response to environmental variability and to obtain quantitative estimates of possible changes. Several experiments were carried out to monitor the model phytocenosis response to the changes in the concentrations of nutrients in the sea water. The setting of a quasi-stable state of the system after an abrupt change (10-fold) in the concentrations of nitrogen and phosphorus in the sea water was simulated. Changes in the uptake rates, specific growth rate and nitrogen and phosphorus content in tissues were monitored. It was found that the system reaction to a decrease in concentrations depends on the molar ratio N/P in the water and their initial concentration. So, at an initially high concentration of nutrients in the water $\left(\left[\mathrm{NO}_{3}\right]=23 \mu \mathrm{M},\left[\mathrm{NH}_{4}\right]=5 \mu \mathrm{M}\right)$, the relative decrease in the specific growth rate is significantly less than at low concentrations $\left(\left[\mathrm{NO}_{3}\right]=3 \mu \mathrm{M},\left[\mathrm{NH}_{4}\right]=0.1 \mu \mathrm{M}\right)$. Fig. $5 b-d$ illustrates the relative changes in the specific growth rate and nutrient uptake rates $\left(\frac{\Delta V_{\mathrm{NO}_{3}}}{V_{\mathrm{NO}_{3}}}, \frac{\Delta V_{\mathrm{P}}}{V_{\mathrm{P}}}\right)$ for two abovementioned concentrations of nitrogen 
compounds in the water and two ratios of nitrogen to phosphorus: N/P $=10$ and $\mathrm{N} / \mathrm{P}=20$. In Fig. 5, $a$ the dynamics of setting a new stationary state of the system, characterized by a decrease in the relative nitrogen content (formula (4)) in the tissues of all algae types, is represented.

It is obvious that 5 components of the phytocenosis adapt to the changed situation quickly enough, while a new quasi-stationary state with lower algae growth rates and increased uptake rates is set. Due to the low rates of metabolic processes (Tables 1 and 2), Cystoseira and Phyllophora do not have time to reach a stationary state during the experiment, while the nitrogen-limiting function (4) decreases in them, limiting the growth rate. When the concentration of nutrients decreases by a factor of 10 , the algae growth rate decreases within the range of $20-60 \%$ at high initial concentration and $60-80 \%$ at a low one. At a ratio of $\mathrm{N} / \mathrm{P}=10$, the decrease in specific growth rates of most macroalgae is less, and the percentage increase in uptake rates is greater. This phenomenon is explained by the fact that phosphorus acts as a limiting element for all algae with an increase in N/P ratio.
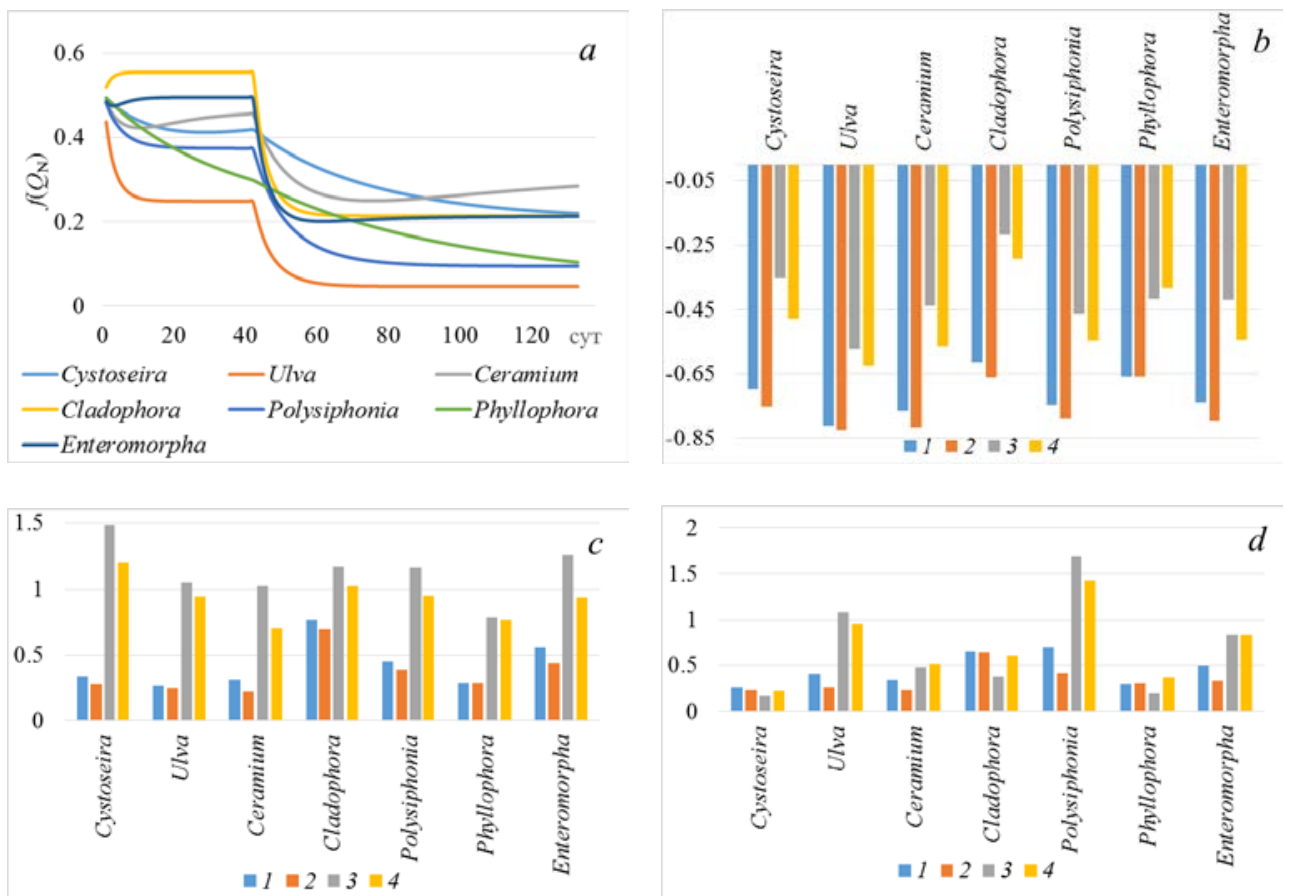

F i g. 5. Relative changes in the system characteristics at the 10-fold drop of the nitrogen and phosphorus concentrations in seawater: tissue saturation with nitrogen (at initial concentrations $\left.\left[\mathrm{NO}_{3}\right]=3 \mu \mathrm{M},\left[\mathrm{NH}_{4}\right]=0.1 \mu \mathrm{M}, \mathrm{N} / \mathrm{P}=10\right)(a)$; specific growth rate $(b)$; nitrogen uptake rate $(c)$; phosphorus uptake rate $(d): 1-\left[\mathrm{NO}_{3}\right]=3 \mu \mathrm{M},\left[\mathrm{NH}_{4}\right]=0,1 \mu \mathrm{M}, \mathrm{N} / \mathrm{P}=10 ; 2-\left[\mathrm{NO}_{3}\right]=3 \mu \mathrm{M}$, $\left[\mathrm{NH}_{4}\right]=0,1 \mu \mathrm{M}, \mathrm{N} / \mathrm{P}=20 ; 3-\left[\mathrm{NO}_{3}\right]=23 \mu \mathrm{M},\left[\mathrm{NH}_{4}\right]=5 \mu \mathrm{M}, \mathrm{N} / \mathrm{P}=10 ; 4-\left[\mathrm{NO}_{3}\right]=23 \mu \mathrm{M}$, $\left[\mathrm{NH}_{4}\right]=5 \mu \mathrm{M}, \mathrm{N} / \mathrm{P}=20$

A minimal decrease in the growth rate is demonstrated by Cladophora, the maximum - by Ulva, Ceramium, Polysiphonia and Enteromorpha, especially at PHYSICAL OCEANOGRAPHY VOL. 27 ISS. 3 (2020) 
low initial concentrations of nitrogen and phosphorus in the tissues. The plants increase the nutrient uptake rate to maintain internal reserves in the deficiency conditions. The maximum increase in uptake rates can reach $150 \%$ compared with the initial rate. Different species react differently to the reduction of nitrogen and phosphorus reserves but they all set a new quasi-stationary N/P ratio in tissues, adapting to changing living conditions. Such flexibility allows macroalgae to increase their biomass even at low concentrations of nutrients in the water.

\section{Conclusion}

The proposed simulation model provides adequate assessments of the volumes of the substances absorbed and released by the bottom phytocenosis and can be used as a block of the coastal zone ecological model. In addition, the model can be used to describe the macroalgae mariculture in a comprehensive environmental model that includes mariculture objects. Simulation experiments with the model provide material for studying the system response to changes in external effects, such as temperature, solar radiation and concentration of nutrients in the sea water. This is necessary for a better understanding of the dynamics of metabolic processes occurring in the sea coastal zone. However, when performing such experiments, a prerequisite is the placement of model algae in the "natural environment", i.e. the creation of a competitive interaction between macroalgae objects in the model. This is possible only within the framework of a comprehensive chemical-biological model. The dynamics of water masses have an additional effect on the phytocenosis functioning; therefore, the inclusion of a hydrodynamic block into the ecosystem model is also a prerequisite for obtaining adequate assessments. In this vein, this work can be considered as a necessary first step, providing a better understanding of the model internal dynamics.

The limitations of the obtained results and conclusions are primarily associated with the estimates of photosynthetic and kinetic parameters of the system. In order to make the values of these characteristics more precise further laboratory experiments are required.

\section{REFERENCES}

1. Kovardakov, S.A., Kovrigina, N.P. and Izmest'eva, M.A., 2004. [Benthic Phytocenosisin the Water Area up to the Aiya Cape and Its Contribution to the SelfPurification Process]. In: MHI, 2004. Monitoring Systems of Environment. Sevastopol: MHI, pp. 250-257 (in Russian).

2. Chopin, T., 2013. Aquaculture, Integrated Multi-Trophic (IMTA). In: P. Christou, R. Savin, B.A. Costa-Pierce, I. Misztal and C.B.A. Whitelaw, (eds.), 2013. Sustainable Food Production Publisher: New York, NY. https://doi.org/10.1007/978-1-4614-5797-8_173

3. Kim, J.K., Kraemer, G.P. and Yarish, C., 2014. Field Scale Evaluation of Seaweed Aquaculture as a Nutrient Bioextraction Strategy in Long Island Sound and 
the Bronx River Estuary. Aquaculture, 433, pp. 148-156. doi:10.1016/j.aquaculture.2014.05.034

4. Chopin, T., 2017. The Renewed Interest in the Cultivation of Seaweeds, as the Inorganic Extractive Component of Integrated Multi-Trophic Aquaculture (IMTA) Systems, and for the Ecosystem Services They Provide. Bulletin of the Aquaculture Association of Canada, 1, pp. 13-18. Available at: https://aquacultureassociation.ca/wp-content/uploads/2017/01/Bulletin-2017-1.pdf [Accessed: 10 June 2020].

5. Latala, A. 1990. Photosynthesis and Respiration of Some Marine Benthic Algae from Spitsbergen. Polar Research, 8(2), pp. 303-307. https://doi.org/10.3402/polar.v8i2.6822

6. Taylor, R.B., Peek, J.T.A. and Rees, T.A.V., 1998. Scaling of Ammonium Uptake by Seaweeds to Surface Area: Volume Ratio:Geographical Variation and the Role of Uptake by Passive Diffusion. Marine Ecology Progress Series, 169, pp. 143-148. doi:10.3354/meps169143

7. Johansson, G. and Snoeijs, P., 2002. Macroalgal Photosynthetic Responses to Light in Relation to Thallus Morphology and Depth Zonation. Marine Ecology Progress Series, 244, pp. 63-72. doi:10.3354/meps244063

8. King, R.J. and Schramm, W., 1976. Photosynthetic Rates of Benthic Marine Algae in Relation to Light Intensity and Seasonal Variations. Marine Biology, 37(3), pp. 215-222. https://doi.org/10.1007/BF00387606

9. Nielsen, S.L. and Sand-Jensen, K., 1990. Allometric Settling of Maximal Photosynthetic Growth Rate to Surface/Volume Ratio. Limnology and Oceanography, 35(1), pp. 177-180. https://doi.org/10.4319/lo.1990.35.1.0177

10. Gordillo, F.J.L., Dring, M.J. and Savidge, G., 2002. Nitrate and Phosphate Uptake Characteristics of Three Species of Brown Algae Cultured at Low Salinity. Marine Ecology Progress Series, 234, pp. 111-118. doi:10.3354/meps234111

11. Hein, M., Pedersen, M.F. and Sand-Jensen, K., 1995. Size-Dependent Nitrogen Uptake in Micro- and Macroalgae. Marine Ecology Progress Series, 118, pp. 247253. doi:10.3354/meps118247

12. De los Santos, C.B., Pérez-Lloréns, J.L. and Vergara, J.J., 2009. Photosynthesis and Growth in Macroalgae: Linking Functional-form and Power-scaling Approaches. Marine Ecology Progress Series, 377, pp. 113-122. doi:10.3354/meps07844

13. Wu, H., Shin, S.K., Jang, S., Yarish, C. and Kim, J.K., 2018. Growth and Nutrient Bioextraction of Gracilaria chorda, G. vermiculophylla, Ulva prolifera, and U. compressa under Hypo- and Hyper-osmotic Conditions. Algae, 33(4), pp. 329-340. doi:10.4490/algae.2018.33.11.13

14. Young, E.B., Dring, M.J., Savidge, G., Birkett, D.A. and Berges, J.A., 2007. Seasonal Variations in Nitrate Reductase Activity and Internal N Pools in Intertidal 
Brown Algae are Correlated with Ambient Nitrate Concentrations. Plant, Cell \& Environment, 30(6), pp. 764-774. doi:10.1111/j.1365-3040.2007.01666.x

15. Vasechkina, E.F. and Filippova, T.A., 2019. Modeling of the Biochemical Processes in the Benthic Phytocenosis of the Coastal Zone. Physical Oceanography, 26(1), pp. 47-62. doi:10.22449/1573-160X-2019-1-47-62

16. Milchakova, N.A. 2015. Current State of Macrophytobenthos in Karadag Nature Reserve and Adjacent Objects of the Marine Protected Area (Crimea, the Black Sea). In: A.V. Gayevskaya and A.L. Morozova, eds., 2015. 100 years of the T.I. Vyazemsky's Karadag Scientific Station: issue of scientific papers. Simferopol: N. Orianda, pp. 506-523. Available at: https://repository.marineresearch.org/handle/299011/547 [Accessed: 9 November 2019] (in Russian).

17. Khailov, K.M. and Burlakova, Z.P., 1969. Release of Dissolved Organic Matter by Marine Seaweeds and Distribution of Their Total Organic Production to Inshore Communities. Limnology and Oceanography, 14(4), pp. 521-527. doi:10.4319/lo.1969.14.4.0521

18. Minicheva, G., Kosenko, M. and Shvets, A., 2009. Phytobenthos of the Large and Small Phyllophora Fields as a Reflection of the Contemporary Ecological State of the Northwestern Black Sea. Morskoj Ehkologicheskij Zhurnal = Marine Ekological Journal, 8(4), pp. 24-40. Available at: https://repository.marineresearch.org/bitstream/299011/1034/1/Minich_Phyllophora_text.pdf [Accessed: 7 November 2019] (in Russian).

19. Milchakova, N., 2011. Marine Plants of the Black Sea : An Illustrated Field Guide. Sevastopol: DigitPrint, 144 p. doi:10.21072/978-966-02-5801-3

20. Afanasyev, D.F., Kamnev, A.N., Sushkova, E.G. and Steinhagen, S., 2016. Ecological Physiology of Aquatic Phototrophic Organisms. The field Guide to Ulva Species Found in the Black, Azov, Caspian Seas and Eastern Baltic. Moscow: Publishing house «Pero», 51 p. Available at: http://azniirkh.ru/wpcontent/uploads/2017/03/Field_guide_to_Ulva.compressed.pdf [Accessed: 20 June 2020] (in Russian and English).

21. Kesava Rao, Ch. and Indusekhar, V.K., 1987. Carbon, Nitrogen \& Phosphorus Ratios in Seawater \& Seaweeds of Saurashtra, North West Coast of India. Indian Journal of Marine Sciences. 16(2), pp. 117-121. Available at: http://nopr.niscair.res.in/bitstream/123456789/38489/1/IJMS\%2016\%282\%29\%201 17-121.pdf [Accessed: 20 June 2020].

22. Baghdadli, D., Tremblin, G., Pellegrini, M. and Coudret, A., 1990. Effects of Environmental Parameters on Net Photosynthesis of a Free-Living Brown Seaweed, Cystoseira barbata Forma Repens: Determination of Optimal Photosynthetic Culture Conditions. Journal of Applied Phycology, 2(3), pp. 281-287. doi:10.1007/BF02179786

23. Dangan-Galon, F., Dumilag, R.V. and Ganzon-Fortes, E.T., 2013. PhotosynthesisIrradiance Curves of Four Marine Macroalgae from Bolinao, Pangasinan and Calatagan, Batangas, Philippines. Scholarly Journal of Scientific Research and Essay, 2(8), $\quad$ pp. 134-138. Available at: 
https://www.researchgate.net/profile/Floredel_Galon2/publication/307545014_Photosynthesisirradiance_curves_of_four_marine_macroalgae_from_Bolinao_Pangasinan_and_Calatagan_ Batangas_Philippines/links/57c7d28608ae28c01d4f9037/Photosynthesis-irradiance-curves-offour-marine-macroalgae-from-Bolinao-Pangasinan-and-Calatagan-Batangas-Philippines.pdf [Accessed: 20 June 2020].

24. Wallentinus, I., 1984. Comparisons of Nutrient Uptake Rates for Baltic Macroalgae with Different Thallus Morphologies. Marine Biology, 80(2), pp. 215-225. https://doi.org/10.1007/BF02180189

25. Rees, T.A.V., 2003. Safety Factors and Nutrient Uptake by Seaweeds. Marine Ecology Progress Series, 263, pp. 29-42. doi:10.3354/meps263029

26. Popovichev, V.N. and Egorov, V.N., 2009. Kinetic Regularities of Exchange of Phosphorus by the Black Sea Brown Seaweed Cystoseira Barbata. Morskoj Ehkologicheskij Zhurnal = Marine Ekological Journal, 8(1), pp. 55-66. Available at: https://repository.marine-research.org/handle/299011/1000 [Accessed: 10 November 2019] (in Russian).

27. Runcie, J.W., Ritchie, R.J., Larkum, A.W.D., 2003. Uptake Kinetics and Assimilation of Inorganic Nitrogen by Catenella nipae and Ulva lactuca. Aquatic Botany, 76(2), pp. 155-174. doi:10.1016/S0304-3770(03)00037-8

28. Finenko, Z.Z., Churilova, T.Ya., Sosik, H.M. and Basturk, O. 2002. Variability of Photosynthetic Parameters of the Surface Phytoplankton in the Black Sea. Oceanology, 42(1), pp. 53-67. Available at: https://www.whoi.edu/science/B/sosiklab/Finenko_etal_Oceanology2002.pdf [Accessed: 10 November 2019].

29. Sovga, E.E., Godin, E.A., Plastun, T.V. and Mezentseva, I.V., 2014. Assessment of Hydrochemical Regime of the Yalta Bay Coastal Waters. Morskoy Gidrofizicheckiy Zhurnal, (3), pp. 48-59 (in Russian).

30. Atkinson, M.J. and Smith, S.V., 1983. C:N:P Ratios of Benthic Marine Plants. Limnology and Oceanography, 28(3), pp. 568-574. https://doi.org/10.4319/lo.1983.28.3.0568

31. Khaylov, K.M., Prazukin, A.V., Kovardakov, S.A. and Rygalov, V.E., 1992. Functional Morphology of Marine Multicellular Algae. Kiev: Naukova Dumka, 280 p. Available at: https://repository.marine-research.org/handle/299011/1464 [Accessed: 9 November 2019] (in Russian).

32. Kovardakov, S.A. and Prazukin, A.V., 2012. Structural and Functional Characteristics of the Bottom Seaweeds Community in Kruglaya Bay (Sevastopol). Optimization and Protection of Ecosystems, (7), pp. 138-148. Available at: http://ekosystems.cfuv.ru/wp-content/uploads/2016/11/E7_17.pdf [Accessed: 10 June 2020] (in Russian).

About the authors:

Elena F. Vasechkina - Deputy Director on Scientific, Methodological and Educational Work, Marine Hydrophysical Institute of RAS (2 Kapitanskaya Str., Sevastopol, 299011, Russian Federation), Dr. Sci. (Geogr.), ORCID ID: 0000-0001-7007-9496, Scopus Author ID: 6507481336, ResearcherID: P-2178-2017, vasechkina.elena@gmail.com 
Tat'yana A. Filippova - Engineer, Marine Hydrophysical Institute of RAS (2 Kapitanskaya Str., Sevastopol, 299011, Russian Federation), ORCID ID: 0000-0001-5762-5894, Scopus Author ID: 56190548500, ResearcherID: AAO-5512-2020, deryabina1993@yandex.ru

Contribution of the co-authors:

Elena F. Vasechkina - development of the conceptual model and the modelling approach, planning the simulations, analysis of modeling results, text writing

Tat'yana A. Filippova - analysis of the published data on the macroalgae functional morphology, performance of numerical experiments, analysis of simulation results

The authors have read and approved the final manuscript.

The authors declare that they have no conflict of interest. 